\title{
STRENGTHENING TEACHER PREPARATION THROUGH A LIBRARY PROGRAM
}

\author{
by \\ John D'Amicantonio and Jordan M. Scepanski
}

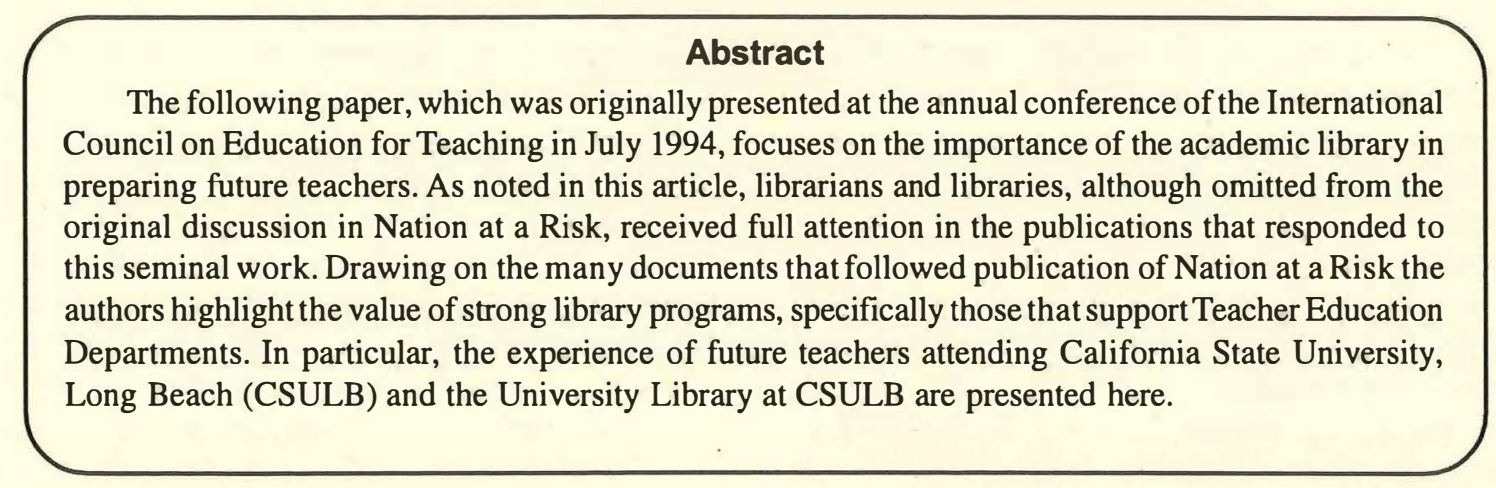

\section{Introduction}

The preparation of the individuals most critical to attainment of educational excellence - elementary and secondary school teachers - can be enhanced by a strong library program and essential, ongoing development of teachers in the field can be facilitated by partnerships with libraries. This paper focuses on one such program at a university that is a major producer of teachers in the United States and describes what is being done to link libraries more effectively with teachers, students of teaching, and teaching educators.

Few would disagree that the defining event affecting primary and secondary education in the United States in recent years was the issuance of the report of the National Commission on Excellence in Education, A Nation at Risk: the Imperative for Educational Reform (National Commission on Excellence in Education, 1983). Publication of the commission's findings in April of 1983 sparked widespread concern and discussion and spawned conferences, seminars, and follow up reports, including a number relating to commission recommendations concerning teacher preparation. ${ }^{*}$ But if release of $A$ Nation at Risk was a wake up call for the American education community (and for the country in general), it was to many in the library profession a shock and a disappointment. Librarians, no less than teachers, administrators, and parents, were aware of the plight of kindergarten through twelfth grade education in the United States of the early 1980's, but few expected a national commission on educational excellence to ignore libraries almost totally in its analysis and recommendations. Some, like Richard Dougherty in Libraries and the Learning Society suggested that "the erosion in the quality of education" was "not due to a decline in libraries or library services.

* See for example: A Call for Change in Teacher Education (Washington, D.C.: American Association of Colleges for Teacher Preparation) 1985. A Nation Prepared: Teachers for the Twenty-First Century (New York Carnegie Forum for Education and the Economy) 1986. Tomorrow's Teachers: A Report of the Holmes Group (East Lansing, MI: The Holmes Group) 1986.
Libraries are not judged central to the current problem," he wrote, because "the problem is one of deficiencies in basic skills such as reading and writing, which "school educators and not librarians... are trained to teach" (American Library Association, 1984, p. 5). Nevertheless, as Joseph Schubert (American Library Association, 1984) indicates in his forward to Libraries and the Learning Society: Papers in Response to A Nation at Risk, most librarians "expressed surprise and sometimes indignation at the commission's failure to refer explicitly to the role of libraries in educational reform" (p. V). Recognizing this oversight, the U.S. Department of Education's Center for Libraries and Education Improvement convened a meeting of library leaders in September of ' 83 to take up the role of libraries in the renewal of American primary and secondary education. Papers were commissioned for a series of seminars held throughout the country to elicit recommendations on how libraries and librarians could contribute to the improvement of education, and a report, Alliance for Excellence, was issued in July of 1984 (U. S. Department of Education, 1984). In Alliance for Excellence a number of statements and recommendations are found that either directly or by implication speak to how libraries and librarians can contribute to the improvement of teacher training. In his preface to Alliance, U.S. Secretary of Education Terrell H. Bell, who had appointed the national commission, wrote: "To assure survival in this difficult age, there is a need to elevate the United States to the standard of a lifelong Learning Society." He went on to say "... a librarian not only holds the keys to the knowledge that is the prelude to tomorrow but also is equipped to show every citizen how to access the future and live with confidence in the Learning Society" (U.S. Department of Education, 1984, pp. iiiiv).

\section{The University}

California State University, Long Beach (CSULB) is among the largest of the campuses of the California State University (CSU) system. The CSU, in turn, is one of the largest systems of higher education in the United States having approximately 325,000 
students and over 16,000 faculty at 22 institutions stretching from San Diego, near the Mexican border up to Arcata near the border state of Oregon, a distance of almost 1,500 kilometers. California divides higher education into three components: two-year community colleges; comprehensive institutions covering undergraduate studies and graduate offerings through the Master degree; and research universities offering undergraduate and graduate degrees including the doctorate. The CSU makes up the second of these segments and among its most important purposes is the preparation of teachers. It has been estimated that the CSU educates ten percent of the kindergarten through 12 th grade teachers in the United States.

CSULB is located in Long Beach, a city of some 450,000 people, fifth most populous in the state and 32 nd in the country. Long Beach is situated approximately 30 miles south of downtown Los Angeles on the Pacific Ocean. In 1996/97 CSULB had 27,431students representing each of 47 American states and territories as well as 109 foreign nations. Many of these students were pursuing their studies on a part-time basis. Approximately 1,000 students were enrolled in the university's Graduate College of Education and another 1,500 were engaged in some sort of credential work through other colleges in the university.

The College of Education at CSULB is a graduate program with two departments: Educational Psychology, Counseling and Administration; and Teacher Education. Since 1949 over 30,000 individuals, many of whom now teach in the elementary and secondary schools of California, in other states throughout the country, and in other countries, have received credentials in teaching or education-related support services from the university. First among the California programs producing teachers, the College of Education provides courses for traditional K-6 instructors, as well as for single subject teachers on the secondary level. In addition, the college prepares educational support personnel in the areas of school administration, special education, school counseling, and library-media services. In the last ten years particular attention has been focused on offerings concerned with California's changing demographics. For instance, the college's Educational Psychology, Administration and Counseling Department has programs in educating the leaming and the severely handicapped, both programs with a bilingual focus. Internships with area school districts are available for students concentrating in these areas.

Recognizing the need for international competencies the College of Education has been among the first to offer courses in international education. Specializations exist in language, literacy, and culture. These focused programs offer students opportunity to pursue English as a Second Language training and to study linguistics. Another program developed in response to the changing population in California is the Bilingual Emphasis Credential in Mathematics, Spanish, and Social Science.

\section{The Library}

When measured by volume count, the California State University, Long Beach Library is one of the largest in the world among Masters'-level institutions. With holdings of more than a million volumes and significant collections of media materials, it surpasses in size libraries at many doctoral universities. A staff made up of librarians, media production specialists, technicians, and clerical and supporting personnel provide comprehensive instructional and academic support functions. An online catalog, the central component of an integrated library management system which has been in place since the mid-1980's, is accessible to the campus community within the library and the university's New Media Center, a separate facility on the opposite end of campus from the library, via the university's high-speed communications network, and through dial-up access from offices and homes. The library also provides access to remote data files and electronic indexing and abstracting services, and to full-text digitized documents, in CD-ROM format. Database offerings number in the sixties, with those more heavily used-such as the important education file, ERIC (Educational Resources Information Center)-networked to permit simultaneous remote access by students and faculty. In addition, students and faculty may access online database systems via remote access. Systems such as Carl UnCover and FirstSearch provide access to a number of databases from off campus which include ERIC and several other related databases for research purposes. The library also expects to begin a reserve documents imaging project which will digitize materials frequently used by students and thereby make them accessible via workstations. Many of the items currently available only in the "reserve room" will then be obtainable in other areas of the library and elsewhere on and off campus.

\section{Supporting Teacher Preparation}

In an analysis of the reforms recommended by teacher education groups Jo Ann Carr and Kenneth Zeichner (Breivik, 1988) as cited in Libraries and the Search for Academic Excellence noted that changes envisioned in the type of education programs, in academic and field experiences, and in professional autonomy, would have significant implications for librarians:

Academic librarians serving teacher education programs must take a proactive position in the integration of information access, materials analysis and instructional design skills in the academic and clinical curriculum. They must work with faculty in strengthening resources for teacher education, and in providing a collegial model, in order to ensure the creation of the professional teacher (Breivik, 1988, p. 90 ).

The library at CSULB has a long tradition of contributing to the education of teachers at the university and over the past decade has engaged in a number of efforts to enhance its programs and services in this area. Library collections include 35,000 monographs, 1,735 serial titles, several thousand curriculum guides, over 200 separate teaching aids, a major textbook collection and approximately 20,000 juvenile literature titles. Among the latter are all those on the California Department of Education's "Recommended Literature" list and national award-winning children's books. There is also a large collection of slides, filmstrips, 
video cassettes, and other audio visual material relevant to education, childhood development, teacher preparation, and learning approaches. Supplementing education holdings are federal documents including many from the U.S. Department of Education. The library is a U.S. government document depository. These materials are available to all campus users and to the general public, but are selected with teacher educators and students of education in mind. This collection is enhanced by documents of the State of California including all subject area frameworks taught in California's schools.

The library works closely with all university departments in selecting journal titles and in purchasing other print and non-print materials. A representative elected by each teaching department meets regularly with the librarian assigned to the particular discipline. Through a consultative process, appropriate choices are made to reflect current trends in educational research. Books, periodicals, and other materials are chosen which enhance the education student's effectiveness as a teacher. Books are ordered directly based upon faculty recommendations or after having come to the attention of the librarian through reviews or other mechanisms, but they also are obtained on approval from several vendors who assist in finding appropriate materials. These vendors automatically send titles that fit a profile developed by the subject librarian in consultation with the faculty.

Librarians at Cal State Long Beach - indeed, librarians throughout the California State University System - are fullfledged faculty members who teach, conduct research, and participate in faculty governance. Many have graduate degrees in subject disciplines in addition to librarianship. The librarian whose primary assignment is working with the College of Education, for example, holds Masters degrees in Education and in Library Science and is a former secondary school teacher. Librarians are assigned subject areas corresponding to their interests, expertise, and education. In addition to general reference work, they are responsible for lecturing in the classrooms of their faculty colleagues and consulting on information approaches and issues.

Alliance for Excellence stresses the need to improve library instruction in both the schools and in teacher education: "College and university libraries should ... provide subject-oriented bibliographic instruction so that students will master information skills for use both in formal academic pursuits and thereafter in the Learning Society" (American Library Association, 1984). One means of improving bibliographic instruction is through lectures that reflect the same skills and processes that the future teachers themselves are honing. At CSULB the education librarian conducts more than 20 subject related lectures a year for students in the Teacher Education Department and numerous others in subject disciplines in which prospective teachers are enrolled. The subject related classes are arranged with the College of Education faculty. Each faculty member arranges with the education librarian a oneand-a-half to two hour session in the library which has several classrooms available for instruction. In addition, several electronic classrooms with computer stations are available for instruction in the library computer lab. Emphasis is on searching appropriate databases like ERIC and PsycLIT (Psychology Literature) and on assessing the relevance of the information found. In addition to covering these two critical databases on CD Rom, "surfing" the Internet is also taught in many of the subject based lectures as well as the FirstSearch and UnCover database systems each of which is accessible on the net. Each lecture begins with a behavioral objective for the particular session. For example, instruction in the use of ERIC would start off with an indication that by the end of the class students will be able to complete a search with 90 percent accuracy and know how to print and download appropriate information. Beaubien et al. (1982) refer to such a statement as an "enabling objective." Objectives of this type include 4 basic elements:

1. someone completing the action (in this case, the class);

2. a given time period (by the end of the class);

3. what the class is expected to do (search, print or download); and

4. one or more criteria to judge (90\% accuracy) (Beaubien, 1982, p. 33).

While not having a direct recommendation about libraries the National Commission did state that students should "understand the computer as an information device." Among the earliest training in use of computers provided students at Cal State Long Beach is that made available by the library through an introductory workbook-based exercise, taught in a one unit class for all undergraduates, and in subject-related lectures. Most important in the training of teachers is information gathering using electronic sources. Over the last twenty years libraries have seen a dramatic shift from emphasis on traditional printed sources to digitized formats, especially those found in online databases and in CD ROM software. This shift has required even stronger partnerships between teacher education departments and the libraries that support them. Where in the past most education faculty members have felt reasonably conversant with the bibliography of their areas, and more or less comfortable in teaching approaches to the literature on their own, the veritable explosion of information world-wide and the need to organize and control it by machine has led to greater dependence on information specialists such as librarians. The ability of computers to store vast amounts of data efficiently, to rearrange references in a variety of ways, and to search comprehensively has brought about the possibility of much better informed faculty members and students, but the complexities of searching protocols and differing interfaces has made the teaching role of the librarian ever more important and collaboration with the faculty more essential. Adapting to this change library lectures in teacher education have moved from emphasizing the use of printed materials alone to both manual and electronic information gathering. The change in technology itself is enough to convince most faculty that librarians, the information specialists, play an increasingly important role in preparing future teachers.

At CSULB students are trained (in subject specific lectures) in how to find information in a variety of CD-ROM-based data files, but equally important, they are taught a critical thinking process intended to help them analyze the data discovered. This approach provides the teacher trainee with both a method of 
learning and an important teaching technique. With appropriate objectives clearly stated, lectures by the librarians take students through use of a database thesaurus, logical selection of descriptors, search of the file, and analysis of the information found to determine if it is accurate and useful. The group is then instructed in identification of bibliographic descriptors such as journal title, volume, pages, and date of publication, and how to determine if a particular periodical is held by the library.

Also covered in the lectures are printed sources that will lead students to additional material. These include such publications as the Current Index to Journals in Education (CIJE), Resources in Education (RIE), Higher Education Abstracts, and Exceptional Children.

Beginning in the spring 1996, the library offered Education students and faculty lectures on how to find information on the Internet, the international network of computers. These lectures focus on searching appropriate web sites as well as learning the specifics on the Internet, specifically FTP, E-mail and browsing. Effective use of the Internet will make available to the College of Education a vast array of material, much of it designed for elementary and secondary teachers. For example, included on the U.S. Department of Education's website are links to: Office of Educational Research and Improvement statistics; information from the Office of Elementary and Secondary Education including curriculum guides; announcements, bulletins, and press releases; educational software; grant program guidelines and applications; math and science education material; and library program data. Also found are educational research and development studies; vocational education items; and postsecondary education reports.

Examples of additional resources available through the Internet, but from sources other than the U.S. Department of Education, include delivery options for the daily report card; lesson plans; electronic-mail lists; children's literature and curriculum listservs; a discussion forum on talented and gifted students; and materials on second language acquisition and on research and teaching.

In his paper prepared for the Libraries and the Learning Society (American Library Association, 1984) project, "Stemming the Tide' of Mediocrity," Richard Dougherty, in a section titled "Training the Trainers," suggests:

Librarians can play a more active role in providing instruction to students who are actively working to earn teaching degrees. Courses could be organized jointly under the aegis of the library and the College of Education. The purpose would be to offer future teachers a foundation of knowledge and an appreciation of library and information science (p. 12).

Because of the burgeoning growth of informational resources, especially those in digitized formats, discussion has begun at the university about the possibility of offering classes on information access and assessment for credit. Initial consideration is being given to two or three credit courses in the College of Business Administration, but the College of Education, as a professional school with students who could particularly benefit from such instruction, is seen as a place where such electives would have direct relevance. The courses would emphasize sources related to the study of and research on teaching and would be taught by the education librarian. More recently, discussion regarding offering general education courses in information literacy is taking place in several official forums on campus. Librarians have also been invited to meet with teaching faculty in the College of Liberal Arts to discuss the importance of information literacy in traditional undergraduate liberal arts classes.

A unique program resident within the College of Education which is extremely valuable to students pursuing teacher training is an electronic learning center housing computer work stations which provide access to a range of CD-ROM products and online databases. Funded by grants from the state of California, the center solicits CD-based learning materials from publishers for use by teacher education students, faculty members, and teachers in the Los Angeles metropolitan area. The intent is to have prospective teachers and those already out in the field become familiar with electronic learning tools which might ultimately find their way into the classrooms, computing laboratories, and libraries of Southern California school districts. Publishers are willing to provide their software products free of charge to the center which is located in a building adjacent to the library in exchange for the opportunity for wide-scale viewing of their wares. The center's director, a College of Education faculty member with a degree in library science conducts regular demonstration sessions for CSULB students and faculty, and for area teachers and librarians. CSULB librarians are called upon by her to provide orientation to the campus setting and to help teach use of electronic resources such as those found in the center.

\section{Connecting to the Community}

"We recommended that librarians ... develop and implement plans to share the resources and services of their institutions in support of education and lifelong learning." (U.S. Department of Education, 1984, p. 37)

The electronic learning center is but one example of a program that connects California State University, Long Beach with the community in which it is located and which fosters not only preparation of new teachers, but professional advancement of those already in the schools. In addition to the linkage provided by the electronic learning center, the University Library's administration and librarians initiated dialog in the early 1990's with three other local institutions (Long Beach Unified School District, Long Beach City College, and the Long Beach Public Library) to discuss the possibility of resource sharing among the group's libraries. The group will seek electronic linkage of existing online catalogs in order to coordinate better expenditure of scarce acquisitions dollars and to share expensive books and journals. Where online catalogs do not presently exist - such as in many of the libraries of the school district - attempts will be made to remedy the situation by fundraising and by sharing technology.

Librarians of the school district and the university are aware that much can be done to share resources and expertise through regular contact and communication. Meetings between the Long 
Beach Unified School district's high school librarians, its library coordinator, and administrators and librarians from the university have taken place at which a number of areas of cooperation have been explored. The high school librarians have been provided borrowing privileges at the university library - privileges previously accorded medical librarians in the city and soon to be extended to others as well - and in- service training for them, conducted by the university's education librarian, has focused on resources, services, and the library's instructional program. Knowledge of the respective instructional programs by the high school and university librarians is important in order to assure that students entering the university have basic information gathering skills and that duplication of eff ort does not occur. As Dougherty writes, "There should be a logical progression in the teaching of library strategies beginning with the primary schools and continuing steadily through college ... concepts and techniques learned in high school need not and should not be repeated" (American Library Association, 1984, p. 13).

CSULB is in dialog with a nearby high school about the possibility of adding its bibliographic records to the database of university books and periodicals which now reside on the campus mainframe. Should that prove affordable and feasible, the school district would have available to it a sophisticated online system beyond any it could hope to obtain on its own. In addition, with a connection now existing between the catalogs of the public and university libraries, students in the high school will be able to search the holdings of the public library from their individual sites. This would be extraordinarily beneficial to them because with declining budgets for new acquisitions, students are increasingly dependent upon public library branches for informational and reading materials. The students might be able to take advantage of the university library's periodical indexing and abstracting databases as a new system utilizing common searching language and highend equipment is put in place.

Beyond the obvious benefits to students (and to the general public which will have available more information about a greater array of material), "Linking of the Libraries" in Long Beach has important implications for both teacher preparation and teacher development. College of Education students would be able to access information not only about holdings in their own university library, but in those of the public, community college, medical, and special libraries, and in individual schools, as well. They and their faculty instructors and mentors would be able to work with knowledge about library collections as they actually exist in the schools and would be able to relate their studies to the reality of school information resources. They also would be better prepared to instill in their future students the need for life-long learning of which libraries of all kinds are an important element.

Through connection of the libraries, teachers in the school system would be better able to keep abreast of current developments in teacher education and might look at the university as less separated and uninvolved in their worlds. Too often universities are viewed as elitist institutions disconnected from the communities in which they exist. An electronic connection of the libraries would be one step in breaking down such an image. It could also lead to a true community information network that would benefit all.

Linkage of the libraries is an initiative of the Long Beach Community Partnership (LBCP), a coalition of businesses, governmental agencies, educational institutions, and citizens. The partnership seeks to strengthen the local economy, increase the marketable skills of its residents, and improve the quality of life in Long Beach neighborhoods (UPDATE, 1994). To do so it sees the necessity of a "world class" educational system and has invited the chief executive officers of the school district, the community college, and the university to engage in planning which would assure a "seamless" educational structure within the city. The partnership has promised to pursue funding for projects which would further this objective, and has expressed enthusiasm for the prospect of library linkage.

\section{Conclusion}

In concluding his response to A Nation at Risk, Dougherty suggests that reversing the decline that prompted the national commission's call to arms would not be quickly accomplished: "More than a generation was required for the erosion of our education establishment... and it will take more than a generation to restore ... and to instill into our society an appreciation of the importance of life-long reading and learning ..." We have found that it certainly takes more than a decade to address the myriad of problems facing education and "the best technology society can provide and adequate funding" (American Library Association, 1984, p. 14) that Dougherty called for is not yet found in most schools. Even at CSULB where there is much success as a result of the relationship between the College of Education and the library as outlined in this paper there are still many hurdles. For example, not all faculty in the College of Education are willing to arrange for library instruction for their classes. It is the responsibility of the education librarian to meet with faculty new and old each year and convince them of the usefulness of such instruction. Similarly, many students in the teacher education programs still balk at attending library lectures. Some education faculty make attendance at library lectures an option resulting in some students opting out and consequently never receiving the necessary instruction. This is combated by regular meetings between the College of Education faculty and the education librarian. Progress is being made, however, which is demonstrated by the increasing number of students in our teacher preparation programs that do attend library lectures and learn that libraries play an important role in teacher preparation. 


\section{References}

American Library Association. American Association of School Libraries (1990). Initial Programs for the School Library Media Specialist. Emergency Librarian, 17, 19-21.

American Library Association (1984). Libraries and the Learning Society. Chicago: American Library Association.

Beaubien, A. \& Hogan, S.A. \& George, M.W. (1982) Learning the Library. New York: R.R. Bowker Co.

Best, R. (1990). Teaching Skillsfor Learning: Information Skills in Initial Teacher Education. Chicago: American Library Association.

Breivik, P.S. \&Wedgeworth, R. (Eds.). (1988). Libraries and the Searchfor Academic Excellence. Metuchen, NJ: Scarecrow Press.

Caywood, C. (1991). Beginning with Teachers. School Library Journal, 37, 52.

Damerell, R.G. (1985). Education's Smoking Gun: How Teachers Colleges Have Destroyed Education in America. New York: Freundlich Books.

An Educational Laboratory: Bank Street College (1989). School Librarian's Workshop, 9, 4-5.

Gordon, L.D. (1989). Reaching Student Teachers. School Library Journal, 35, 51.

Hall, N. (1988). Teachers Information and School Libraries. Library Association Record, 90(1), 35-36.

Hamilton, D. (1989). On the Other Hand: On Becoming a Teacher-Librarian. School Libraries in Canada, 9(Winter): 9.

James, R. (1985). Teacher Education Students - Different Needs, Different Solutions. In J. Fletcher (ed.), Reader Services in Polytechnic Libraries (pp. 140-141). Hants, England: Gower.

Jones, A. (1989). Using School Library Resources as Part of Initial Teacher Training. The School Librarian, $37,9$.

National Commission on Excellence in Education (1983). A Nation at Risk: The Imperative for Educational Reform. Washington, D.C.: Government Printing Office.

O'Hanlon, N. (1987). Library Skills, Critical Thinking, and the Teacher-Training Curriculum. College and Research Libraries, 48, 17-26.

Olson, L.E. (1992). Learning: The Ultimate End. School Library Media Activities Monthly, 9(1), 31,47.

Roberts, F.X. (1990). An Early Example of a Curriculum Materials Collection in an Institution of Teacher Education. Behavioral and Social Sciences Librarian, 9, 21-28.

Teclehaimanot, B. (1992). Curriculum Materials Centers in Teacher Education: Trends for the 1990's. Ohio Media Spectrum, 44(1), 38-41.

UPDATE (1994). Long Beach, CA: Long Beach Community Partnership, Inc.

U.S. Department of Education (1984). Alliance for Excellence: Librarians Respond to a Nation at Risk. Washington, D.C.: Government Printing Office.

\section{About the Co-authors}

John D'Amicantonio, Associate Librarian, California State University, Long Beach is the Education and Psychology Librarian for the University Library at Cal State Long Beach. Mr. D'Amicantonio received his M.S. Ed. from the State University of New York at New Paltz in 1981 and his M.S.L.S. at The Catholic University of America in 1986. He has traveled extensively throughout Asia on library business in addition to visiting Turkey in 1994 where he, along with coauthor Jordan Scepanski, first delivered a paper on the topic of libraries and their importance in supporting teacher education.

Jordan M. Scepanski is the Executive Director of the Triangle Research Libraries Network, a consortium of Duke, North Carolina State and North Carolina Central Universities, and the University of North Carolina at Chapel Hill. From 1984 to 1996 he was Director of Library and Learning Resources at California State University, Long Beach, and during 1995 he served as Senior Advisor for Library Affairs at the CSU Office of the Chancellor. He has worked as a university library administrator in Tennessee, and North Carolina and has taught as a Fulbright Lecturer in Library Science at Hacettepe University in Ankara, Turkey. His research and writings have focused on library personnel, library change, and the future of libraries. He has consulted on organization development and conducted program reviews at a number of university libraries in the United States and abroad. 